Instructions for authors, subscriptions and further details:

http://rasp.hipatiapress.com

\title{
List of Reviewers 2015
}

Date of publication: January $30^{\text {th }}, 2016$

Edition period: January 2016 - July 2016

To cite this article: (2016). List of Reviewers 2015. Research on Ageing and Social Policy, 4(1), 153. doi: 10.17583/rasp.2016.1885

To link this article: http://doi.org/10.17583/rasp.2016.1885

\section{PLEASE SCROLL DOWN FOR ARTICLE}

The terms and conditions of use are related to the Open Journal System and to Creative Commons Attribution License (CCAL). 
RASP - Research on Ageing and Social Policy Vol. 3 No. 1

July 2016 p. 153

\section{List of Reviewers 2015}

We deeply appreciate reviewers' contributions to the quality of this journal during 2015. Yours sincerely,

Alfredo Alfageme

Luis Ayuso

Editors

Anderson, Nicole

De Miguel, Verónica

Durán-Muñoz, Rafael

Fernández, Mercedes

Fernández-Carro, Celia

García, Livia

García-Bacete, Francisco

García-Pastor, Begoña

González, $\mathrm{M}^{\mathrm{a}}$ Nieves
Hernández Peinado, Manuel

Martínez del Castillo, Jesús

McLaughlin, John

Ortega, Marta

Plaza, Juan F.

Sánchez Martínez, Mariano

Spijker, Jeroen

Torrent, Rosalia

Trinidad, Antonio 